\title{
Experimental Meniscal Allografts in the Rabbit
}

\author{
L. PAŠA ${ }^{1}$, A. NEČAS ${ }^{2}$, I. PIPERISOVÁ ${ }^{2}$, H. KECOVÁ ${ }^{2}$, P. VIŠŇÁ ${ }^{3}$, F. TICHÝ ${ }^{4}$ \\ ${ }^{1}$ Clinic of Traumatology, Medical Faculty Masaryk's University Brno, Czech Republic \\ ${ }^{2}$ Department of Surgery and Orthopaedics, Small Animal Clinic, Faculty of Veterinary Medicine, \\ University of Veterinary and Pharmaceutical Sciences, Brno, Czech Republic \\ ${ }^{3}$ Department of Traumatology, Clinic of Surgery, Medical Faculty, Charles University, Praha, \\ Czech Republic \\ ${ }^{4}$ Department of Anatomy, Histology and Embryology, Faculty of Veterinary Medicine, \\ University of Veterinary and Pharmaceutical Sciences, Brno, Czech Republic
}

Received July 23, 2004

Accepted March 3, 2005

\begin{abstract}
Paša L., A. Nečas, I. Piperisová, H. Kecová, P. Višňa, F. Tichý: Experimental Meniscal Allografts in the Rabbit. Acta Vet. Brno 2005, 74: 87-95.

Meniscal injury belongs to most common consequences of stifle trauma in humans. Its treatment usually consists of partial meniscectomy; this procedure, however, predisposes the knee to progression of gonarthrosis and thus increases morbidity and subsequently raises drug consumption. Progression of pathologic changes often leads to implantation of total knee prosthesis. With development of arthroscopy, the number of salvage procedures of injured menisci increased. This method also reduces progression of arthrotic changes. However, not every meniscal lesion is reparable and not every reinserted meniscus will heal. That is why the number of performed meniscectomies is still high.

The purpose of this study was to verify on experimental model if transplantation of fresh and frozen medial meniscal allografts into the stifle joints after total meniscectomy reduces progression of gonarthrosis. Progression of arthrotic changes in stifle joints after total meniscectomy was evaluated in three groups of 8 rabbits: group 1: rabbits after total meniscectomy without meniscal transplantation (control); group 2: meniscectomy followed by transplantation of fresh meniscal allograft; group 3: transplantation of deep frozen $\left(-80^{\circ} \mathrm{C}\right)$ meniscal allograft. The results of surgical procedures were evaluated both clinically and radiographically. The quality of allograph incorporation was evaluated both macroscopically and histologically 4 months after the surgery.

Severe osteoarthritis developed in rabbits after total meniscectomy. In both groups after meniscal transplantation, allografts healed with well functional stifles and progression of gonarthrosis was reduced comparing to the group of rabbits after meniscectomy alone. The extent of arthrotic changes was smaller after transplantation of frozen allografts than after transplantation of fresh allografts. Histology of stifles with fresh meniscal transplants showed more pronounced perivascular inflammatory infiltration in site of transplant insertion to the joint capsule than in the frozen allografts. Promising results of this study need to be verified in clinical cases.
\end{abstract}

Medial meniscus, allograft, osteoarthritis, stifle joint, knee, rabbit

Meniscal injury belongs to most common consequences of stifle trauma in both humans (Paša et al. 2004) and animals (Duval et al. 1999; Nečas and Zatloukal 2002). It commonly accompanies anterior/cranial cruciate ligament (ACL/CCL) ruptures (Arnoczky 1993; Nečas et al. 2000). Etiology of ACL/CCL ruptures has been studied for many years (Niebauer and Menzel 1982; Vasseur et al. 1985; Arnoczky 1993; Duval et al. 1999; Faldy na et al. 2004). Methods of diagnosis and subsequent treatment of meniscal lesions were described already in 19th century by Thomas Annandal (cit. Lo et al. 2002) with favourable to excellent outcome after removal of injured meniscus during arthrotomy. In later years it was shown that following meniscectomy the affected stifle compartment is subjected to excessive forces with early wear out of the articular cartilage (Mow et al. 1992; Krause et al. 1976; Fairbank 1948). Chondromalacia and 
subsequent arthrotic lesions lead to stifle joint pain, swelling and decreased range of motion (ROM).

With the recognition of meniscal role in normal joint function, attempts to save the injured meniscus have been made. In 1883 Thomas Annandal was the first to describe suture of torn meniscus, when he repaired the cranial horn of medial meniscus; the patient was able to return to work 10 weeks after the surgery with fully functional stifle joint (cit. Cannon 2002). First arthroscopically-assisted meniscal repair was done in 1969 by Ikeuchi (1976). In 1970 DeHaven and Hales (1981) performed meniscal repair through posteromedial or posterolateral arthrotomy. Meniscal suture became a widespread method of meniscal injury repair after 1980, when Henning (1983) developed instruments for the "inside-out" technique. In recent years in our country the trend has also been towards the attempts of salvage procedures with reinsertion of the injured menisci - suture and meniscopexy (Drápal 1993). The results of these procedures seem to be satisfactory (Henning 1983; Drápal 1993). Results of our primary study of allogen connective tissue transplantation into joint (allotransplantations of ligaments) are also promising ( $\mathrm{Paša} \mathrm{et} \mathrm{al.} \mathrm{2001).}$

Localization of meniscal tear and blood supply to the affected area are important factors for healing of the lesion. Fibrocartilaginous meniscus is supplied with blood from two sources (Arnoczky 1992). First source are blood vessels that reach only to the basis of meniscus; towards the inner margin of the meniscus (medial and lateral) these vessels almost disappear. According to extent of its blood supply, the meniscus on cross sectional view can be divided into three parts: external part, so called "red zone", has rich blood supply from synovial membrane. It comprises approximately $1 / 4$ of the meniscus. Towards inner margin of the meniscus lies relatively narrow, so called intermediate or "red-white zone", where the vessels occur only sporadically and so called "white zone", completely without blood supply (Arnoczky 1992). Synovial fluid is the second, less important source of nutrients for menisci (Swann and Radin 1972).

When injured (torn), the affected part of the meniscus looses its nutrient supply. After its reinsertion, the healing process is the same as in cases of autogenous ligamentous graft (Arnoczky 1992; O'Donoghue et al. 1971). It has been proven that in treatment of cruciate ligament ruptures with autologous graft transplantation, the graft first undergoes necrosis and after that revascularisation occurs (O' Donoghue et al. 1971). Healing of allogenous ligament that was deeply frozen $\left(-80^{\circ} \mathrm{C}\right)$ before implantation occurs in the same manner. The idea of transplantation of allogenous meniscal grafts into knees after total meniscectomy is based on experience with salvage procedures of menisci and with implantation of allogenous ligamentous grafts. The incorporation of allogenous meniscus into well vascularised joint capsule can be anticipated.

This article summarises results of an experimental study on meniscal allograft transplantation in rabbits. The purpose of the study was to evaluate the quality of incorporation of fresh and deep frozen allogenic menisci to the joint capsule and to evaluate the extent of arthrotic changes in the stifle joints after total meniscectomy in comparison with joints after total meniscectomy and subsequent transplantation of fresh or deep frozen meniscal allograft, respectively.

\section{Materials and Methods}

New Zealand white rabbit was chosen as an experimental animal model. Twenty-four healthy individuals, of same sex (males), same age ( 8 months) and approximately same weight $(2 \mathrm{~kg})$ were included in the study. They were reared under laboratory conditions. Rabbits were divided into 3 groups of 8 individuals:

Group 1 (control) - rabbits of this group underwent total meniscectomy of medial meniscus of the right stifle joint. The menisci were immediately after excision implanted into right stifle joints of recipient animals (rabbits of group 2) after total meniscectomy of medial meniscus (see below group 2).

Group 2 - rabbits of this group underwent total meniscectomy of medial meniscus of the right stifle joint, which was followed by transplantation of fresh allograft of medial meniscus from the rabbits of group 1. Excised medial 
menisci of animals in group 2 were rinsed in sterile saline solution and deep frozen $\left(-80^{\circ} \mathrm{C}\right)$ (Arnoczky et al. 1988; Arnoczky et al. 1992). Under these conditions they were stored for a period of one week and after that transplanted to the animals of group 3 (see below group 3).

Group 3 - rabbits of this group underwent total meniscectomy of medial meniscus of the right stifle joint, which was followed by transplantation of deep frozen allograft of medial meniscus from the rabbits of group 2 . The menisci were slowly defrosted in sterile saline solution at room temperature (Arnoczky et al. 1992) right before transplantation.

Surgeries were performed under general anesthesia. Induction was achieved by intramuscular administration of medetomidine in the dose of $200 \mu \mathrm{g} / \mathrm{kg}$ (DOMITOR inj. a.u.v., Pfizer) and ketamine $10 \mathrm{mg} / \mathrm{kg}$ (NARKAMON 5\% inj., Léčiva). Total intravenous anesthesia (TIVA) was then maintained with propofol in the dose of 0.15 $\mathrm{mg} / \mathrm{kg} / \mathrm{h}$ (PROPOFOL ABBOTT inj., Abbott Lab). Rabbits were placed in dorsal recumbency and the surgical site was routinely prepared for aseptic procedure. Medial arthrotomy (horizontal joint capsule incision) was performed cranially and caudally to the medial collateral ligament of the right stifle joint. Joint capsule was carefully separated from the medial edge of medial meniscus (basis of the meniscus). After dissection of cranial and caudal insertion of the medial meniscus, total meniscectomy was completed. In the first group of rabbits, the joint capsule was reinserted and sutured to the medial collateral ligament (Prolene 4/0) and the wound was closed rutinely.

In the second and third groups of rabbits, meniscectomy was followed by transplantation of fresh (harvested from the animals of group 1) and deep frozen (harvested from the animals of group 2) menisci, respectively. Menisci were implanted in as physiologic position as was possible and secured in place with interrupted suture with synthetic monophilament non absorbable material (polypropylene, Prolene 4/0). Stitches were placed in outer rim of cranial and caudal meniscal horn and to cranial and caudal aspect of medial collateral ligament. The joint capsule was closed with interrupted suture on medial side of the stifle joint. After the closure, the range of motion of affected stifle was assesed; the acceptable result was full range of motion without any pseudocrepitation. Subcutaneous layer was closed with continuous suture using $2 / 0$ polyglactin 910 (Vicryl). The skin in first four rabbits (two of the group 1 and two of group 2) was closed with interrupted suture using 4/0 polypropylene (Prolene). In all of these rabbits the wound dehiscence after automutilation occurred. Due to this complication, the skin in remaining rabbits was closed with interrupted suture using $2 / 0$ polyglactin 910 (Vicryl). Rabbits with wound dehiscence were anesthetised again and debridement and suture of the wound with polyglactine 910 was performed.

During whole study period, the animals were fed, handled and housed according to the principles of welfare (Sýk or a et al. 1983). The results of surgical procedures were assesed clinically (weightbearing of the affected limb in comparison with contralateral side (the severity of lameness was not quantified), range of motion of the affected joint) and radiographically (stifle on mediolateral and caudocranial view). Radiographic findings were evaluated according to scale of Tapper and Hoover (1969): 0 - no pathology; I - non or small osteophytes, joint space wider than $1 \mathrm{~mm}$; II - small osteophytes, joint space narrower than $1 \mathrm{~mm}$; III - large osteophytes, joint space narrower than $1 \mathrm{~mm}$, or flattening of the femur; IV - large osteophytes, sclerosis of subchondral bone.

At the end of experiment ( 4 months after the surgery), all animals were euthanised using T61 A.U.V. intrapulmonally at a dose of $1.5 \mathrm{ml}$ pro toto. The quality of graft incorporation was evaluated both macroscopically and histologically. All procedures were carried out with consent of the Ethical Committee (No. 46613/2003-1020).

\section{Results}

There were no anesthesia complications in any of the animals. In most rabbits the wounds healed per primam intentionem without any complications. In first four rabbits (two of group 1 and two of group 2) where the skin was sutured with 4/0 polypropylene, within two post op days intense automutilation with consequent dehiscence of the wound occurred (however, the transplanted menisci remained intact). After debridement and secondary suture with polyglactine 910 , all wounds healed primarily.

In rabbits of group 1 (meniscectomy, no transplantation), mild swelling of soft tissues on medial aspect of the affected stifle joints was noted on adspection and palpation. This swelling persisted for the period of two weeks after the surgery. In animals of groups two and three, no swelling was noted.

Animals of all groups were lame on the affected limb for the first week (5-7 days) after the surgery. After this period the weightbearing of affected limb was same as in contralateral limb (no lameness) in all groups. At the end of experiment, no differences were noted in the movement of rabbits of different groups.

Range of motion (ROM) of affected stifle joints differed between the groups at the end of experiment. In healthy stifles, the ROM was $0-140^{\circ}$. In group 1, the ROM was limited in 6 rabbits: maximal extension $40^{\circ}$, maximal flexion $90^{\circ}$. In remaining 2 rabbits of this group, the ROM was normal. In group 2, ROM was not affected in 5 rabbits, and in 
3 cases there was mild limitation (extension $20^{\circ}$, flexion $120^{\circ}$ ). In group 3 , the ROM was not changed in 6 cases and in two rabbits there was mild reduction of ROM (extension $10^{\circ}$, flexion $120^{\circ}$ ).

Radiological findings in affected stifles also differed among the groups. In all animals of the group 1 (meniscectomy), on caudocranial view of the affected limb the joint space in medial stifle compartment was narrowed to absent (Plate III, Fig. 1), with obviously increased contact between articular surfaces of medial femoral condyle and medial aspect of tibial plateau. The radiological findings were consistent with moderate to severe (Fig. 1) arthrotic changes of degree II to IV according to Tapper and Hoover (1969). In animals of group 2 (fresh allograft), the radiographic findings of osteoarthrotic changes on caudocranial view were less severe (Fig. 2) and were consistent with degree I to II (Tapper and Hoover 1969). In 6 animals of this group, small osteophytes on medial aspect of proximal tibia were present. In 3 rabbits, subtle widening of medial femoral condyle was noted; in 2 rabbits medial joint space was slightly narrowed, in 6 animals the joint space was not narrowed at all. In animals of group 3 (deep-frozen allograft), the radiographic findings on caudocranial view were most favourable (Fig. 3); only in three cases there were small osteophytes noted on medial ridge of proximal tibia, and only in 1 case small osteophytes on medial aspect of medial femoral condyle; these findings were consistent with degree 0 to II (Tapper and Hoover 1969).

Macroscopic findings were compared to macroscopic appearence of the contralateral (healthy) stifle of the same individual (Plate IV, Fig. 4). Macroscopic changes correlated with radiographical findings. In all animals of group 1 (meniscectomy), osteophytes on femoral condyles and proximal tibia (more numerous on tibia) were present, with evident fibrillation or abrasion of femoral articular cartilage and almost complete loss of articular cartilage on the medial aspect of tibial plateau ("full thickness lesion") (Fig. 5). In all rabbits of group 2 (fresh allograft), the graft healed in position of medial meniscus (Fig. 6). In 6 animals of this group the necropsy revealed well configurated meniscus, stitches were encapsulated in surrounding soft tissue. In remaining 2 cases, the meniscus itself was thin, but the surrounding synovial membrane was markedly thickened. In all cases in this group there was evident proliferation of synovial membrane surrounding the transplanted meniscus and all menisci were firmly attached to medial ridge of medial aspect of tibial plateau. In all animals of group 3 (deepfrozen allograft), the graft healed in position (Fig. 7). In 7 rabbits of this group, well configurated meniscus was evident, and stitches were encapsulated in surrounding soft tissue. In 2 cases there were small osteophytes visible on the medial ridge of medial femoral condyle. In remaining animals, articular cartilage of medial femoral condyle was only minimally worn out on histological examination, while on macroscopic evaluation it appeared almost normal. In all cases of this group small osteophytes were found on medial ridge of proximal tibia. In one rabbit the necropsy revealed radial tear in implanted meniscus. However, medial ridge of the meniscus was well attached to the joint capsule. In this rabbit there were more prominent osteophytes on medial femoral condyle. In all animals of this group were menisci well attached to the joint capsule as well as to the proximal ridge of medial aspect of tibial plateau.

\section{Histology}

Histology of healthy meniscus

Synovial membrane was hyperplastic, with sporadic mononuclear infiltration, microscopic structure of the meniscus did not differ from normal; occasional minor regions of hyalinisation.

Histology of stifle joints after total meniscectomy

Synovial membrane could not be identified; articular surfaces presented localised irregularities, distribution of chondrocytes in articular cartilage was uniform, with localised 
more pronounced perivascular mononuclear infiltration in fibrose tissue. No dystrophic changes were noted, only minor organised extravasates were present.

Histology of stifle joints after fresh allograft transplantation

Articular surface in fresh allogenic menisci after transplantation was irregular (Plate $\mathrm{V}$, Fig. 8), with focal erosions and localised dystrophic (acellular) areas. Areas of completely smooth, flat cartilage without any signs of degradation were present only sporadically. In deeper layers of meniscal tissue there were areas of hyalinisation, often surrounded by mononuclear infiltrates (especially around stitches and perivascularly). In one case segments were also present. Stitches were usually surrounded by spinocellular demarcation, sometimes with fibrous encirculation. Sporadic residues of minor extravasates were present.

Synovial membrane was mostly hyperplastic, in some cases oedematous, with variable numbers of cells in different localisations. Mononuclear infiltrate was present in almost all cases, sometimes sporadical, other times in dense aggregates (Fig. 9). Areas of hemosiderin and minor extravasates were also present.

\section{Histology of stifle joints after frozen allograft transplantation}

Articular surface of deep frozen menisci after transplantation was in most cases smooth, flat and without erosions (Plate VI, Fig. 10). Only sporadically focal degradations of the surface were present, without surrounding tissue reaction, which could have been caused by manipulation during the surgical procedure. Minor structural defects in meniscal tissue, such as dystrophic foci (Fig. 11) were present sporadically in deeper layers, more commonly surrounding the stitches (in this localisation they were usually accompanied by sparse mononuclear infiltrate). Perivascular infiltrate was in most cases negligible. Rarely (only in one case), extravasate residua were found close to the suture material.

Synovial membrane was in most cases intact, without structural defects. Sporadically (in two cases), indistinctive hyperplasia of synovial villi was present, accompanied by more intense vascularisation, diffuse mononuclear infiltration and areas with minor extravasates.

\section{Discussion}

Salvage procedures such as suture of meniscal lesion enable to optimize future function of injured stifle joint as well as its return to almost the same state as before the trauma (Barret et al. 1998; Klimkiewicz and Shaffer 2002). However, not every meniscus after reinsertion will heal (Post et al. 1997). Its healing is dependent on the type of trauma, vascular supply to the injured part of meniscus, suture technique employed, postoperative care, stability of the stifle and age of the patient (Rockborn and Gillquist 2000; Seil et al. 2000). Moreover, not every meniscal lesion is reparable. Due to above-mentioned factors there is still a quite high number of cases where meniscectomy is the procedure of choice. The number of performed partial and total meniscectomies, however, decreased with introduction of miniinvasive arthroscopic surgeries of stifle joint (North more-Ball et al. 1983). In recent years, even veterinary medicine has been oriented more towards miniinvasivity. Arthroscopically assisted surgeries of stifle joints with ruptured cranial cruciate ligament accompanied by meniscal lesion in dogs became routine procedures (Beale 2000; Hulse 2001; Nečas et al. 2002).

Patients after partial or total meniscectomy often suffer from pain, swelling of the joint and early arthrotic changes. Numerous studies prove more rapid progression of degenerative changes in stifle joints after partial or total meniscectomy (Fairbank 1948; Krause et al. 1976). Transplantation of meniscal allograft in patients after meniscectomy could alleviate or totally eliminate these complications.

Studies on meniscal allograft transplantation published in 1980s and 1990s did not have 
very satisfactory outcomes. With advancement in surgical procedures and adjustment of techniques employed in harvesting, storage and implantation of meniscal grafts, the results of recent studies in experimental (Mikic et al. 1997; Rijk and Van Noorden 2002) as well as clinical practice (Verdonk and Almquist 2002) seem more promising.

The goal of this prospective experimental study was to evaluate function and extent of degenerative changes in stifle joints after total meniscectomy in comparison with stifles after meniscectomy followed by transplantation of fresh or deep frozen meniscal allograft, respectively.

Rabbit was chosen as an experimental animal for its relatively high loading of stifle joint during weightbearing (and thus rapid development of degenerative changes after the surgery), low cost, easy postoperative care and low housing and feeding expencies. On the other hand, the small size of stifle joint and meniscus itself (12-14 mm) was more challenging for the surgical technique. With such petit meniscus, even minor faults during surgical procedure can influence healing of the allograft and progression of arthrotic changes (e.g. above mentioned meniscal tear in one rabbit). Fixation of small menisci in optimal location is relativelly difficult. Despite immediate loading and lack of any immobilization of the stifle joints after surgery, menisci healed without complications.

Considering faster growth and more rapid aging of the rabbit in comparison with humans, selected duration of the experiment ( 4 months) was adequate to evaluate healing of the tissues and progression of arthrotic changes.

Automutilation and subsequent dehiscence of the wound in rabbits with polypropylene (Prolene 4/0) skin suture was probably due to local tissue irritation by this suture material. This theory is supported by the fact, that neither in rabbits with original polyglactine 910 (Vicryl) skin sutures (Cummins et al. 1997; Verdonk and Almquist 2002), nor in these same animals after secondary suture using polyglactin, these complications were noted.

Relation to different groups did not affect the duration nor severity of lameness. Detectable lameness persisted in all animals for average period of one week (5-7 days in all groups) after the surgery. After this period, in animals of all groups weightbearing of affected limb seemed to be normal. However, due to characteristics of movement and weightbearing of pelvic limbs in the rabbit, exact quantifying of lameness in these animals is not possible. That is why this part of clinical evaluation was based on assessment of movement of the affected limb in comparison with contralateral limb of the same animal.

The range of motion of the affected stifle at the end of experiment differed between the groups. It correlated with the extent of arthrotic changes.

When comparing progression of degenerative changes at the end of experiment, distinct differencies between the groups were noted. These differencies included macroscopic as well as radiografic changes and were especially obvious when comparing animals of group one (meniscectomy) with groups two (fresh allograft) and three (deep frozen allograft). Progression of early osteoarthritic changes during the same period was markedly faster in animals of group 1 than in groups 2 and 3. Slight difference was noted even between groups two and three; rabbits after fresh allograft transplantation presented radiographic as well as macroscopic arthrotic changes (mild osteoarthritis) more often than animals after transplantation of deep frozen menisci. In animals of group 3 (deep frozen allograft), arthrotic changes were present least commonly and were least serious. In one case of radial meniscal tear, the most probable cause of this complication was damage during the surgery.

Histology correlated with macroscopic and radiologic findings. In both groups after meniscal transplantation, the meniscal allografts healed well to surrounding tissues of the recipient. Perivascular infiltration as well as proliferation of synovial membrane and small dystrophic foci (probably remnants after minute haematomas) were found more 
frequently in animals with fresh allograft implants (group 2), than in animals with deep frozen menisci.

The results of this experimental study are encouraging. Good healing of meniscal allograft in the recipient site was proved clinically, macroscopically and histologically. In all cases, the allograft healed to medial part of joint capsule as well as to medial ridge of proximal part of tibial plateau (even though it was not sutured to tibial plateau). Extent of osteoarthrotic changes after meniscal transplantation was smaller than in stifles after total meniscectomy itself. Fresh allograft induced more distinct immune-mediated changes (irritation of surrounding tissue) in recipient stifle than frozen allograft.

Meniscal allograft transplantation in both men and animals can help to optimize function of injured stifle joints and to minimize the extent of degenerative changes. Before introducing this method in clinical practice, these results have to be verified in additional clinical studies in animals and humans.

\section{Transplantace allogenních menisků u králíků: experimentální studie}

Poranění menisků patří u lidí mezi nejčastější následky traumat kolenního kloubu. Léčba většinou spočívá v parciální meniskektomii, což predisponuje k rozvoji gonartrózy, zvyšuje se nemocnost, spotřeba léků a často bývá nutná totální endoprotéza. S rozvojem artroskopie přibylo záchovných operací poraněných menisků. Tato metoda také zpomaluje progresi artrotických změn. Je však třeba říci, že ne každá léze menisku je reparovatelná a že ne každý ošetřený meniskus se zahojí. Proto je množství prováděných meniskektomií stále velké.

Cílem této studie bylo ověřit na experimentálním modelu, zda transplantace čerstvého a zamraženého alloštěpu mediálního menisku do kolene po totální meniskektomii omezí progresi artrózy. Rozvoj artrotických změn $\mathrm{v}$ kolenních kloubech po totální meniskektomii byl sledován u 3 skupin králíků po 8 jedincích: skupina 1: meniskektomie bez transplantace (kontrolní), skupina 2: po transplantaci čerstvého allogenního menisku a skupina 3: po transplantaci hluboce zamraženého $\left(-80{ }^{\circ} \mathrm{C}\right)$ allogenního menisku. Výsledek chirurgického zákroku byl hodnocen klinicky a rentgenologicky. Kvalita přihojení alloštěpů byla zhodnocena makroskopicky a histologicky za 4 měsíce po operaci.

U králíků po totální meniskektomii došlo k rozvoji těžké gonartrózy. U obou skupin králíků $\mathrm{s}$ transplantovanými menisky došlo $\mathrm{k}$ přihojení alloštěpů $\mathrm{s}$ dobrou funkcí operovaných kloubů a omezením rozvoje artrózy ve srovnání s jedinci po samotné meniskektomii bez transplantace. Rozsah artrotických změn byl menší po transplantaci zamraženého menisku ve srovnání s čerstvým alloštěpem. V př́ípadě čerstvých alloštěpů byla zaznamenána výraznější perivaskulární zánětlivá infiltrace v místě sutury menisku ke kloubnímu pouzdru, než po transplantaci zamražených menisků. Nadějné výsledky této studie bude třeba ověřit v klinické praxi.

\section{Acknowledgements}

This work was supported by the Ministry of Education, Youth and Sports of the Czech Republic (Research Project No. 161700002) and the Ministry of Health of the Czech Republic (Research Project of IGA MZ CR Reg. No. 8190-3). The authors also thank to Czech Society for Sport Traumatology and Arthroscopy + Aura s.r.o. for technical support.

\section{References}

ARNOCZKY, SP 1992: Gross and vascular anatomy of the meniscus and its role in meniscal healing, regeneration and remodelling. In: MOW, VC, ARNOCZKY, SP, JACKSON, DW: Knee meniscus: basic science and clinical foundation. Raven Press New York, pp. 177-190

ARNOCZKY, SP 1993: Pathomechanics of cruciate ligament and meniscal injuries. In: BOJRAB, MJ: Disease mechanisms in small animal surgery. 2nd ed. Lea \& Febiger Philadelphia, pp. 764-776 
ARNOCZKY, SP, DiCARLO, EF, O’BRIEN, SJ 1992: Cellular repopulation of depp-frozen autografts: an experimental study in dogs. Arthroscopy 8: 428-436

ARNOCZKY, SP, O’BRIEN, S, DiCARLO, E 1988: Cellular repopulation of deep-frozen meniscal allografts-an experimental study in the dog. Trans Orthop Res Soc 34: 145

BEALE, BS 2000: Arthroscopic-assisted stabilization of the cruciate-deficient stifle in dogs using a percutaneous prosthetic ligament-suture anchor technique. Vet Surg 29: 457

BARRET, GR, FIELD, MH, TREACY, SH, TIFF, CG 1998: Clinical results of meniscus repair in patiens 40 years and older. Arthroscopy. J Arthr Rel Surg 14: 824-829

CANNON, WD 2002: Arthroscopic meniscal repair,. In: McGINTY, JB: Operative Arthroscopy. 3rd edition, Lippincott Williams Wilkins, pp. 233-250

CUMMINS, JF, HUMANSSOUR, JN, ZIJUN, H, GORDON, A 1997: Meniscal transplantation and degenerative articular change: An experimental study in the rabbit. Arthroscopy. Journal Arthr Rel Surg 13: 485-491

De HAVEN, KE, HALES, W 1981: Peripheral meniscus repair: an alternative to meniscectomy. Orthop Tran 5: 399-400

DRÁPAL, V 1993: Artroskopická meniskopexe, Acta Chir Orthop Traum Čechosl 60: 96-99

DUVAL, JM,BUDSBERG, SC, FLO, GL, SAMMARCO, JL 1999: Breed, sex, and body weight as risk factors for rupture of cranial cruciate ligament in young dogs. J Am Vet Med Assoc 215: 811-814

FAIRBANK, TJ 1948: Knee joint changes after meniscectomy. J Bone Joint Surg 30B: 664-670

FALDYNA, M, ZATLOUKAL, J, LEVA, L, KOHOUT, P, NEČAS, A, TOHUMANS, M 2004: Lymphocyte subsets in stifle joint synovial fluid of dogs with spontaneous rupture of the cranial cruciate ligament. Acta Vet Brno 73: 79-84

HENNING, CE 1983: Arthroscopic repair of meniscus tears. Orthopedics 6: 1130-1132

HULSE, DA 2001: Arthroscopy of the knee. Proceedings of practical course in arthroscopy and endosurgery. Milovy, Czech Republic, pp. 11-12

IKEUCHI, H 1976: Surgery under arthroscopic control. Proceedings of the Societe Internationale d'Arthroscopie, Rheumatology. Special Issue, pp. 57-62

KLIMKIEWICZ, JJ, SHAFFER, B 2002: Meniscal surgery 2002 update: indications and techniques for resection, repair, regeneration and replacement. Arthroscopy. J Arthr Rel Surg 18: 14-25

KRAUSE, WR, POPE, MH, JOHNSON, RJ 1976: Mechanical changes in the knee after meniscectomy. J Bone Joint Surg 58A: 559-604

LO IAN, KV, THORNTON, G, MINIACI, A, FRANK, CB, RATTNER, JB, BRAY, RC 2002: Basic science. Meniscus. In: McGINTY JB: Operative arthroscopy. 3rd edition, Lippincott Williams Wilkins, pp. 94-102

MIKIC, ZD, BRANKOV, MZ, TUBIC, M V, LAZETIC, AB 1997: Transplantation of fresh-frozen menisci: An experimental study in dogs. Arthroscopy. J Arthr Rel Surg 13: 579-583

MOW, VC, RATCLIFFE, A, CHERN, KY, KELLY, M 1992: Structure and function relationships of the menisci of the knee. In: MOW, VC, ARNOCZKY, SP, JACKSON, DW: Knee meniscus basic and clinical foundations. Raven Press New York pp. 37-57

NEČAS, A, ZATLOUKAL, J 2002: Factors related to the risk of meniscal injury in dogs with cranial cruciate ligament rupture. Acta Vet Brno 71: 77-84

NEĆAS, A, SRNEC, R, KECOVÁ, H 2002: Diagnostic reliability of stifle arthroscopy of pathological changes in cruciate deficient knee. Acta Vet Brno 71: 249-254

NEČAS, A, ZATLOUKAL, J, KECOVÁ, H, DVOŘÁK, M 2000: Predisposition of dog breeds to rupture of cranial cruciate ligament. Acta Vet Brno 69: 305-310

NIEBAUER, GW, MENZEL, EJ 1982:Imunological changes in canine cruciate ligament rupture. Res Vet Sci 32: 235-241

NORTHMORE-BALL, MD, DANDY, DJ, JACKSON, RW 1983: Arthroscopic, open partial and total meniscectomy. J Bone Surg Br 65: 400-404

O'DONOGHUE, DH, FRANK, GR, JETER, GL 1971: Repair and reconstruction of the anterior cruciate ligaments in dogs: factors influencing long term results. J Bone Joint Surg Am 53: 710-718

PAŠA, L, POKORNÝ, V, ADLER, J 2001: Solution of instability of the knee joint by ligamentoplasty using allografts. Acta Chir Orthop Traum âechosl 68: 31-38

PAŠA, L, VIŠŇA, P, KOČIŠ, J, RANDULA, A, KAZDA, S 2004: Výsledky meniskektomií a sutur menisků v klinickém a rtg obraze po 9 letech. Úrazová chirurgie 12: 6-10

POST, WP, AVERS, SR, KISH, V 1997: Load to failure of common meniscal repair techniques: effects of suture technique and suture material, arthroscopy: J Arthr Rel Surg 13: 731-736

RIJK, PC, Van NOORDEN, CJF 2002: Structural analysis of meniscal allografts after immediate and delayed transplantation in rabbits. Arthroscopy. J Arthr Rel Surg 18: 995-1001

ROCKBORN, P, GILLQUIST, J 2000: Results of open meniscus repair. J Bone Joint Surg 82B: 494-498

SEIL, R, RUPP, S, KOHN, DM 2000: Cyclic testing of meniscal sutures. Arthroscopy. J Arthr Rel Surg 16: 505-510

SÝKORA, I, DYNTEROVÁ, A, HOLDA, J, MARHAN, O 1983: Chov laboratorních zvířat. Institut výchovy a vzdělávání MZVž Praha 
SWANN, DA, RADIN, EL 1972: The molecular basis of articular lubrication:I. J Biol Chem 274: 8069-8073

TAPPER, FM, HOOVER, NW 1969: Late results after meniscctomy. J Bone Joint Surg 51A: 517-526

VASSEUR, PB, POOL, RR, ARNOCZKY, SP, LAU, RE 1985: Correlative biomechanical and histologic study of the cranial cruciate ligament in dogs. Am J Vet Res 46:1842-1854

VERDONK, R, ALMQVIST, F 2002: Meniscal transplantation. Tech Knee Surg 1: 23-35 
Plate III

Paša L. et al.: Experimental meniscal allograft ... pp. 87-95
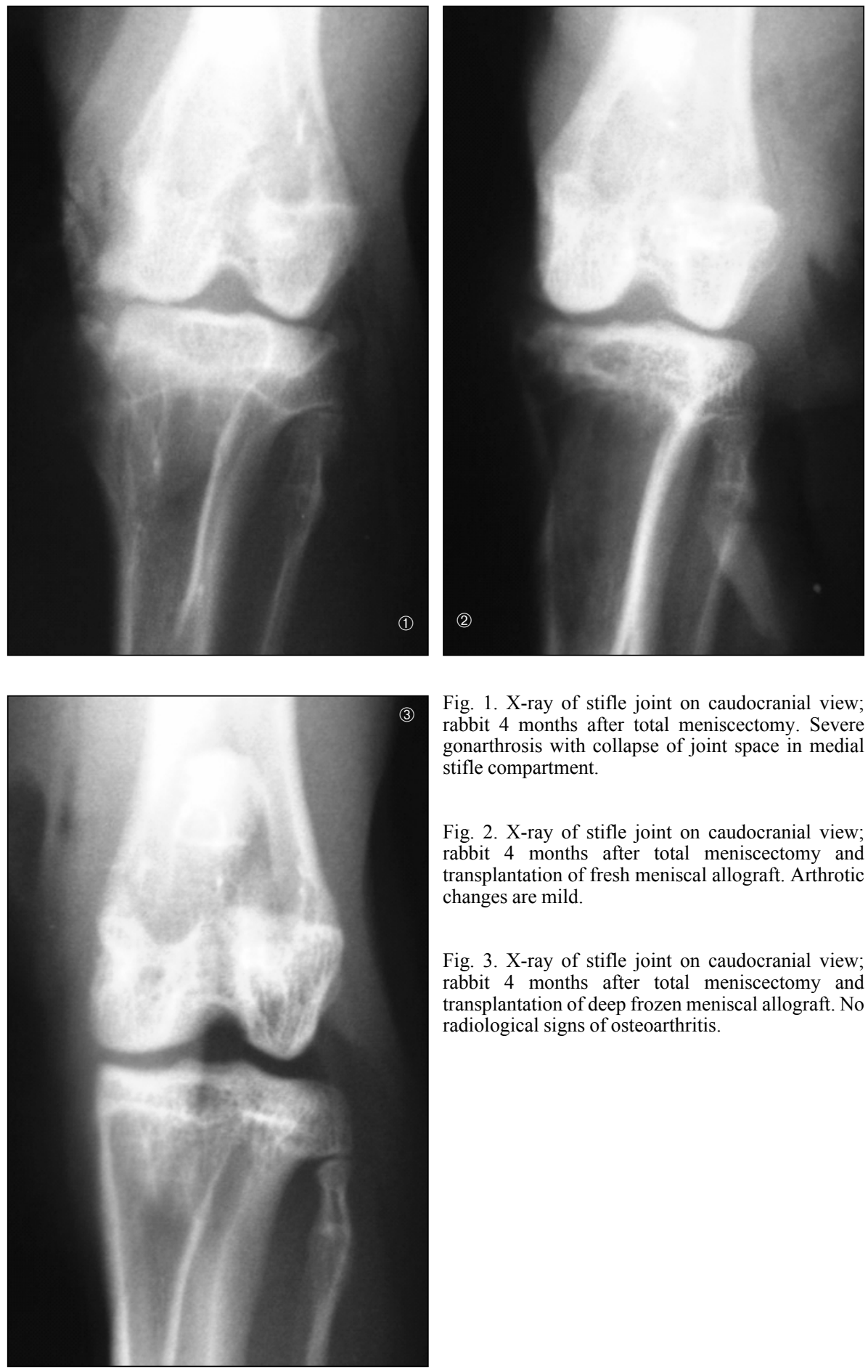

Fig. 1. X-ray of stifle joint on caudocranial view; rabbit 4 months after total meniscectomy. Severe gonarthrosis with collapse of joint space in medial stifle compartment.

Fig. 2. X-ray of stifle joint on caudocranial view; rabbit 4 months after total meniscectomy and transplantation of fresh meniscal allograft. Arthrotic changes are mild.

Fig. 3. X-ray of stifle joint on caudocranial view; rabbit 4 months after total meniscectomy and transplantation of deep frozen meniscal allograft. No radiological signs of osteoarthritis. 


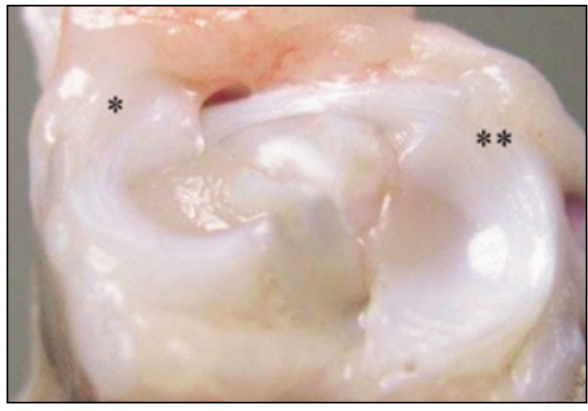

Fig. 4. View on tibial plateau with medial* and lateral** meniscus in healthy (intact) stifle joint of rabbit.

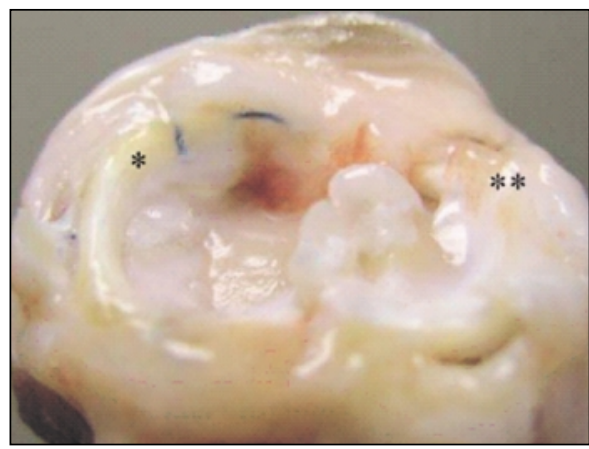

Fig. 6. View on tibial plateau with medial* and lateral** meniscus in rabbit 4 months after meniscectomy and transplantation of fresh allograft of medial meniscus.

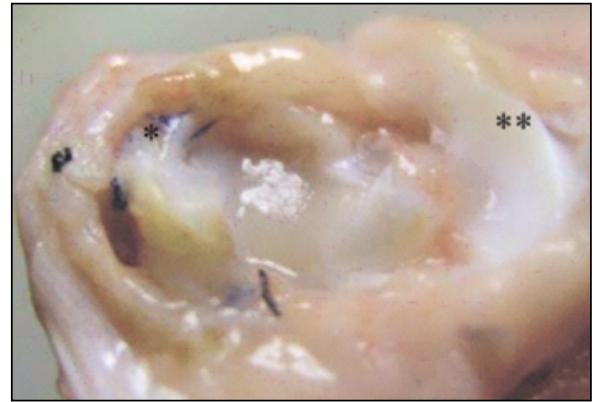

Fig. 5. View on tibial plateau after meniscectomy of medial meniscus* in rabbit 4 months after the surgery. Note lateral meniscus**

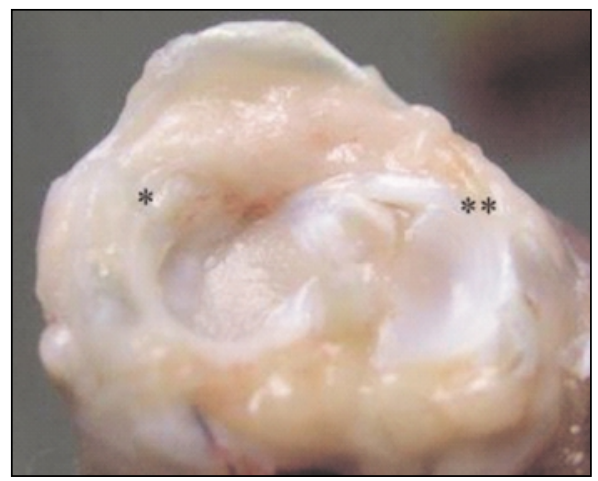

Fig. 7. View on tibial plateau with medial* and lateral** meniscus in rabbit 4 months after meniscectomy and transplantation of deep frozen allograft of medial meniscus. 


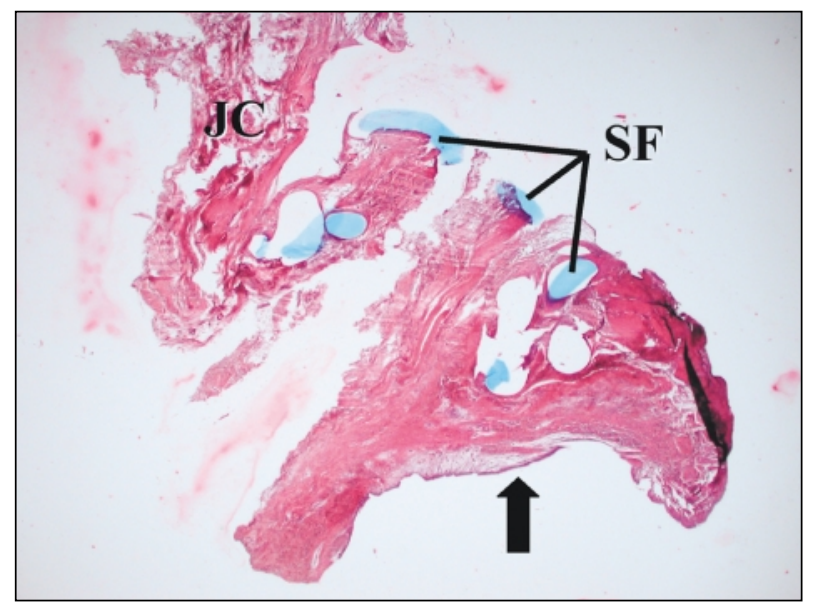

Fig. 8. Transversal section of meniscus; rabbit 4 months after transplantation of fresh allograft of medial meniscus. Articular surface (arrow), fragments of suture material (suture fragments $=\mathrm{SF}$ ), part of joint capsule (JC). HE, $\times 40$.

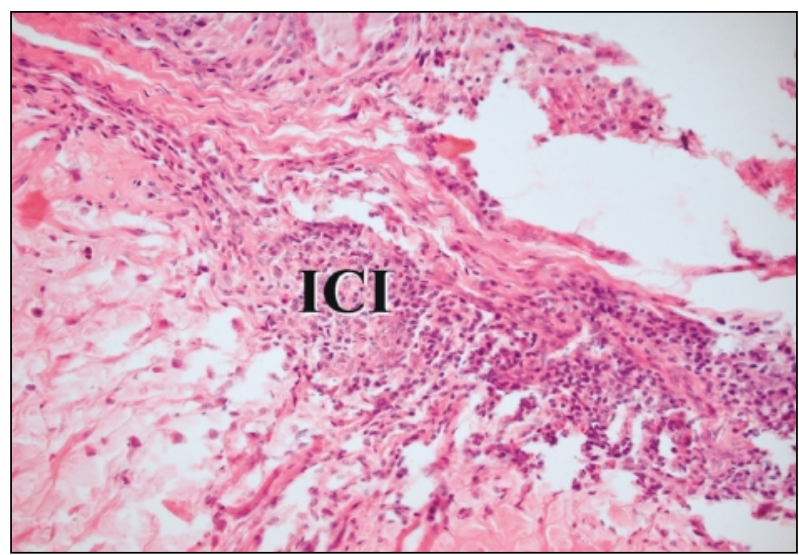

Fig. 9. Part of synovial layer of joint capsule; rabbit 4 months after transplantation of fresh allograft of medial meniscus. Marked inflammatory infiltration (inflammatory cellular infiltration $=\mathrm{ICI}$ ). HE, $\times 250$. 


\section{Plate VI}

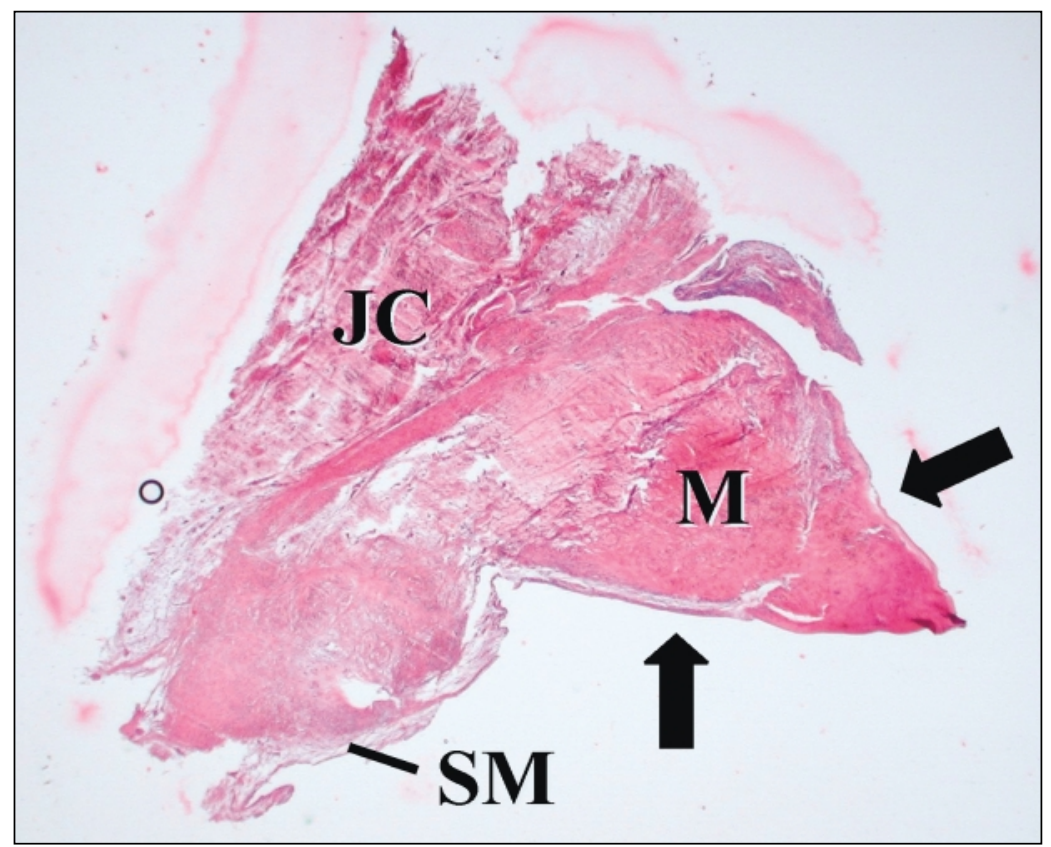

Fig. 10. Transversal section of meniscus; rabbit 4 months after transplantation of deep frozen allograft of medial meniscus. Articular surface (arrows), synovial membrane (SM), meniscal tissue (M) and joint capsule (JC). HE, $\times 40$.

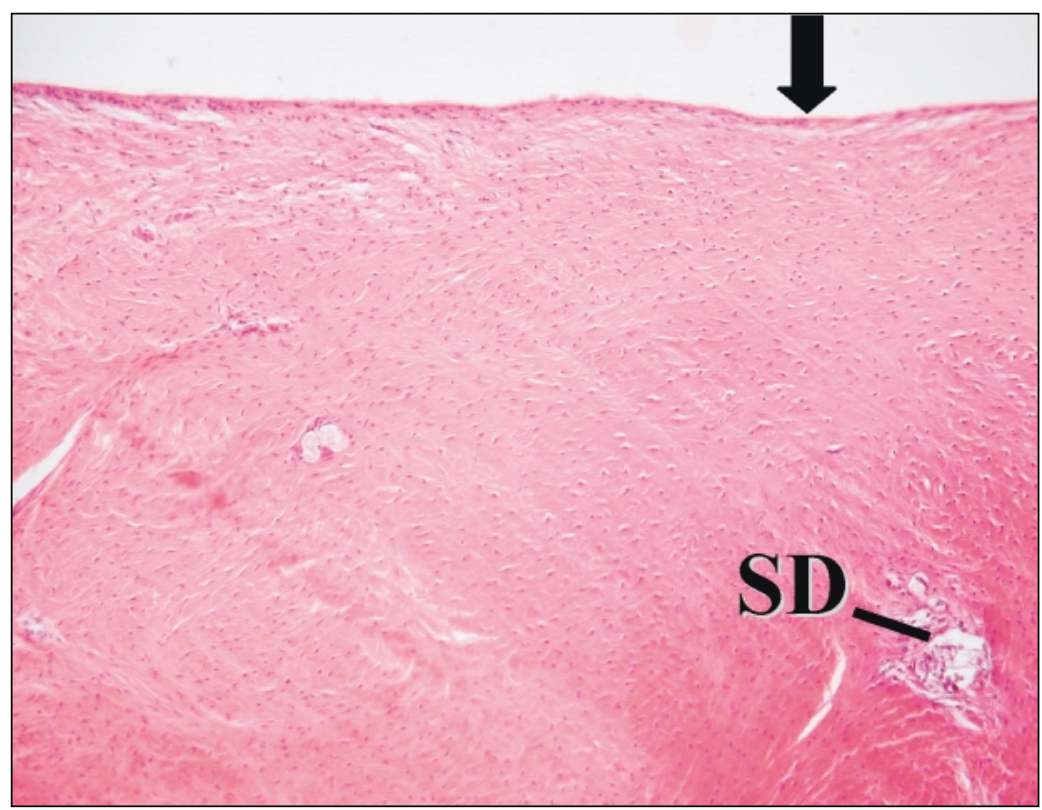

Fig. 11. Articular surface (arrow) of meniscus in a rabbit 4 months after transplantation of deep frozen allograft of medial meniscus. Structural defect in meniscal tissue (SD). HE, $\times 150$. 